\title{
O CTI SOB A ÓTICA DAS PESSOAS DE ENFERMAGEM - UMA ABORDAGEM FENOMENOLÓGICA*
}

\author{
Thelma Spíndola **
}

SPINDOLA, T. O CTI sob a b́tica das pessoas de enfermagem - uma abordagem fenomenológica. Rev.Esc.Enf.USP, v.31, n.1, p. 171-2, abr. 1997.

O estudo resulta de minha preocupação com o conviver dos profissionais de enfermagem no Centro de Terapia Intensiva (CTI). Tem a proposta de entender o cotidiano do CTI aos olhos das pessoas de enfermagem. Para tanto, optei por realizar uma pesquisa qualitativa, com abordagem fenomenológica. Em encontros individuais com enfermeiros e auxiliares de enfermagem de um hospital geral público, coloquei a questão norteadora: ". que significa para você trabalhar em CTI?" A análise dos depoimentos possibilitou caracterizar o trabalho no CTI que é percebido como um local onde se adquire experiência, se desenvolvem atividades complexas e diferenciadas, como também, revestido de cansaço físico e desgaste emocional levandoos, quase sempre, ao estresse. Deparam-se, freqüentemente, com o binômio vida/ morte, o que contribui para se sensibilizarem com o mundo ao seu redor e diferenciálos na instituição hospitalar.

* Resumo da tese de mestrado apresentada à Escola de Enfermagem da Universidade do Rio de Janeiro (UNI-Rio), para obtenção do título de Mestre, em agosto de 1992.

** Enfermeira; Mestre em Enfermagem; Coordenadora do Serviço de Apoio, Planejamento e Supervisão ded Atividades Acadêmicas e Científicas do Hospital Universitário Gaffrée e Guinle, da UNI-RIO; Professora Assistente da Faculdade de Enfermagem da Universidade do Estado do Rio de Janeiro (UERJ). 
SPINDOLA, T. The ICU (Intensive Care Unit) under the vision of the -nursing staff - a phenomenological approach. Rev.Esc.Enf.USP, v.31, n.1, p. 171-2, apr. 1997.

The study is the result of my concerns with the relationships between nurses professionals in the Intensive Care Unit (ICU). It intends to understand the Intensive Care Unit day-by-day routine according to a nurses professional vision. For that I choose to make a qualitative research with a phenomenological approach. Personal interviews with nurses and nursing auxiliaires of a public hospital pointed the guiding question: what does working in a Intensive Care Unit mean to you? The analysis of the testimonys made it possible to characterize the kind of work in an Intensive Care Unit which is sensed as a place where people gets experience, where complex and differents activities are accomplished and that is also physically tiring and emotionally disturbing, frequently leading people to stress. The life/death situation is often presented, which emotionally touches people toward the world and make them distinguish it from the hospital itself. 